\title{
Cold Deformation and Hardness on Superaustenitic Stainless Steel: Evaluation Methods
}

\author{
Breno Mendes Rabelo Avila ${ }^{*}$ (1), André Itman Filho ${ }^{a}$ (), Joũo Alberto Fioresi Altoéa \\ Jaqueline Polezi Mazinia ${ }^{(1)}$, Pedro Gabriel Bonella de Oliveira ${ }^{b}$ (1) \\ anstituto Federal de Educação, Ciência e Tecnologia do Espirito Santo, Programa de Pós-Graduação \\ em Engenharia Metalúrgica e de Materiais (PROPEMM), Vitória, Brasil. \\ ${ }^{b}$ Escola de Engenharia de São Carlos - Universidade de São Paulo, Departamento de Engenharia de \\ Materiais, São Carlos, Brasil.
}

Received: May 15, 2020; Revised: June 21, 2020; Accepted: July 1, 2020

\begin{abstract}
Superaustenitic stainless steel with high nickel percentage, chromium, molybdenum and nitrogen, has replaced austenitic AISI 304 and 316, mainly in the petrochemical industries, where high toughness, stress corrosion resistance and pitting resistance is suitable. Due to high mechanical stress in the cold deformation manufacturing, residual stresses in the pipes are common. In this case, the possibility of the corrosion process increases. Considering the area reduction after tensile tests, the objective of this study was to evaluate the effects of cold deformation on a superaustenitic steel BS EN 10283 № 14587. The steel was elaborated in an electric induction furnace and the liquid metal was poured out in sand molds. Afterward, samples cut from a specimen submitted to the tensile test were prepared for X-ray diffraction, Vickers hardness measurements, linear polarization and impedance electrochemical tests. The corrosion tests were performed in solution with $3.5 \% \mathrm{NaCl}$. The results show that there is a linear increase in hardness and also a decrease in corrosion resistance of the material, with increasing cold deformation. In addition, the cold work reduction was not sufficient to promote strain-induced martensite.
\end{abstract}

Keywords: superaustenitic stainless steel, cold deformation, corrosion.

\section{Introduction}

The superaustenitic stainless steel has as mainly characteristic high corrosion resistance in aggressive environments. According to the literature, the cold deformation influences the mechanical strength and corrosion resistance of stainless steel. In previous work, Speidel and Pedrazzoli studied the effects of cold deformation on conventional stainless steels, such as AISI 304 and AISI $316^{1}$. They observed the deleterious effect of strain-induced martensite on the corrosion resistance of the steels in saline environments. Equation 1 estimates the start temperature Ms at which strain-induced martensite can form, considering the percentage by weight of the chemical elements ${ }^{2}$. In this case, the transformation depends mainly on the chemical composition.

$$
\mathrm{Ms}\left({ }^{\circ} \mathrm{C}\right)=502-810 \mathrm{C}-1230 \mathrm{~N}-30 \mathrm{Ni}-12 \mathrm{Cr}-46 \mathrm{Mo}-54 \mathrm{Cu}
$$

However, under the effect of deformation this temperature is changed. Equation 2 estimates the Ms temperature at which $50 \%$ strain-induced martensite can form after 30\% of deformation, considering the percentage by weight of the chemical elements ${ }^{3}$.

$$
\mathrm{Ms}_{(30 / 50)}\left({ }^{\circ} \mathrm{C}\right)=413-\left[\begin{array}{l}
462(\mathrm{C}+\mathrm{N})+9.2(\mathrm{Si})+8.1(\mathrm{Mn})+ \\
13.7(\mathrm{Cr})+9.5(\mathrm{Ni})+18.5(\mathrm{Mo})
\end{array}\right]
$$

In this case, strain-induced martensite in superaustenitic stainless steels could be formed in negatives temperatures impossible to be reached; while in AISI $316 \mathrm{~L},-10{ }^{\circ} \mathrm{C}$ it

*e-mail: brenomra@gmail.com is sufficient temperature for its formation ${ }^{3,4}$. Nowadays, superaustenitic stainless steels are replacing AISI 304 and AISI 316 to avoid the presence of strain-induced martensite. Superaustenitic stainless steels generally contain nickel in the range of 15 to $35 \%$, chromium 17 to $26 \%$, molybdenum 2 to $5 \%$, nitrogen 0.1 to $0.6 \%$. This composition confers the pitting resistance equivalent number (PREn) greater than 40 and these steels are used in the manufacture of equipment subjected to aggressive environments, such as petrochemical plants, pumps working with salt water, pipes, and fittings in oil exploration in deep water ${ }^{5,6}$.

Considering the interest in studying the materials used in the petrochemical industry, the aim of this paper is to evaluate the effects of cold deformation on superaustenitic stainless steel BS EN 10283 № 14587. In this case, residual stresses were generated by cold deformation on a specimen during the tensile test and the residual stresses were quantified by the cross-sectional area reductions. To evaluate the effects of deformation it was used Vickers hardness tests, X-ray diffraction, optical microscopy, Scanning Electron Microscopy (SEM) and corrosion tests.

\section{Experimental Procedures}

The superaustenitic stainless steel BS EN $10283 \mathrm{~N}^{\circ} 1.4587$ was elaborated in an electric induction furnace with a system for vacuum degasification with a capacity of $1000 \mathrm{~kg}$. The liquid metal was poured into sand molds agglomerated with urethane phenolic resin, and the cast blocks were annealed at $1150{ }^{\circ} \mathrm{C}$ 
for two hours. Five specimens of the steel were cut, and machined according to ASTM E8/E8M to be submitted to tensile tests in a universal test machine, with $1 \mathrm{~mm}$ per minute constant speed. The chemical composition of the steel was obtained by optical emission spectrometry.

After tensile tests, in one of the specimens, small discs with $3 \mathrm{~mm}$ thickness were cut in three different deformed regions. Then, they were prepared according to conventional metallographic methods. The cross-sectional areas were measured with the AutoCAD 2019 software and the microstructures were characterized by backscattering electron images (BSE) in a Scanning Electron Microscope (SEM).

The two transverse faces of each specimen were used in all of the tests. Vickers hardness measurements were carried out with $10 \mathrm{kgf}$ load. In corrosion tests, the solubilized and deformed specimens were immersed in a solution with $3.5 \%$ sodium chloride $(\mathrm{NaCl})$ at room temperature $\left(25^{\circ} \mathrm{C}\right)$. An electrochemical cell for $300 \mathrm{ml}$ of solution with a saturated calomel reference electrode (RE), a platinum counter electrode (CE), and the specimen as a working electrode (WE) was prepared. The electrochemical impedance tests were carried out at open circuit potential (OCP) in the frequency range from $4 \mathrm{mHz}$ to $40 \mathrm{kHz}$ with a potential amplitude of $10 \mathrm{mV}$. The polarization tests were performed with the potential range from $-0.5 \mathrm{~V}$ (vs. OCP) to $1.8 \mathrm{~V}$ (vs. SCE) at a scan rate $1.0 \mathrm{mV} / \mathrm{s}$. The tests were executed in triplicate on both sides of the cross-sectional areas of the specimen. The corrosion potential values were calculated by extrapolation of Tafel, in the linear regions of the anodic and cathodic curves.

\section{Results and Discussion}

The chemical composition shown in Table 1 is in accordance with BS EN 10283. The small discs with $3 \mathrm{~mm}$ thickness, in three different deformed regions, are shown in Figure 1. It is possible to observe that the reduction in area was greater in sample 1, 2 and 3 respectively. Figure 2 shows a dendritic microstructure of the solubilized superaustenitic stainless steel. In stainless steels where the equivalent chromium/equivalent nickel ratio is less than 1.5 , the cast microstructure shows a dendritic distribution of delta ferrite in an austenitic matrix ${ }^{7,8}$. The heat treatment time, without previous mechanical deformation, is not enough to eliminate the dendrites and the microstructure is similar to the superaustenitic stainless steel $22 \mathrm{Cr}-25 \mathrm{Ni}-6 \mathrm{Mo}-0.2 \mathrm{~N}$ observed in the literature ${ }^{9,10}$. In the case of castings, the transformation depends mainly on the chemical composition driving force ${ }^{3}$. Moreover, the stability of austenite during the plastic deformation in these steels is very important, with relation the twinning or martensite transformation ${ }^{11}$. It was found that annealing twins in austenite are effective nucleation sites for spontaneous $\alpha^{\prime}$-martensite ${ }^{12}$. Twinning is reported to occur at stacking fault energies in the range of $18<\mathrm{SFE}<45 \mathrm{~mJ} / \mathrm{m}^{13}$. In addition, increasing the austenitic grain size, reduces the stacking fault energy and increases the Ms temperature and the volumetric fraction of $\alpha$ ' martensite ${ }^{14}$. In the Fe-Cr-Ni system, strain-induced martensite depends mainly on chemical composition, temperature reduction, and reduction of stacking fault energy ${ }^{15}$. In this case, nickel is responsible for increasing the stacking fault energy. Furthermore, in BS EN $10283 \mathrm{~N}^{\circ} 1.4587$ steel, the content of

Table 1. Chemical compositions of superaustenitic steel BS EN $10283 \mathrm{~N}^{\circ} 14587$ (\% in weight).

\begin{tabular}{ccccccccc}
\hline BS EN 10283 $\mathrm{N}^{\circ} 1.4587$ & $\mathrm{C}$ & $\mathrm{Mn}$ & $\mathrm{Si}$ & $\mathrm{Cr}$ & $\mathrm{Ni}$ & $\mathrm{Mo}$ & $\mathrm{Cu}$ & $\mathrm{N}$ \\
\hline Standard & $0.03^{*}$ & $2.0^{*}$ & $1.0^{*}$ & $24.0-26.0$ & $28.0-30.0$ & $4.0-5.0$ & $2.0-3.0$ & $0.15-0.25$ \\
\hline Obtained & 0.03 & 1.2 & 0.74 & 25.0 & 28.4 & 4.3 & 2.4 & 0.20 \\
\hline
\end{tabular}

(*maximum values)

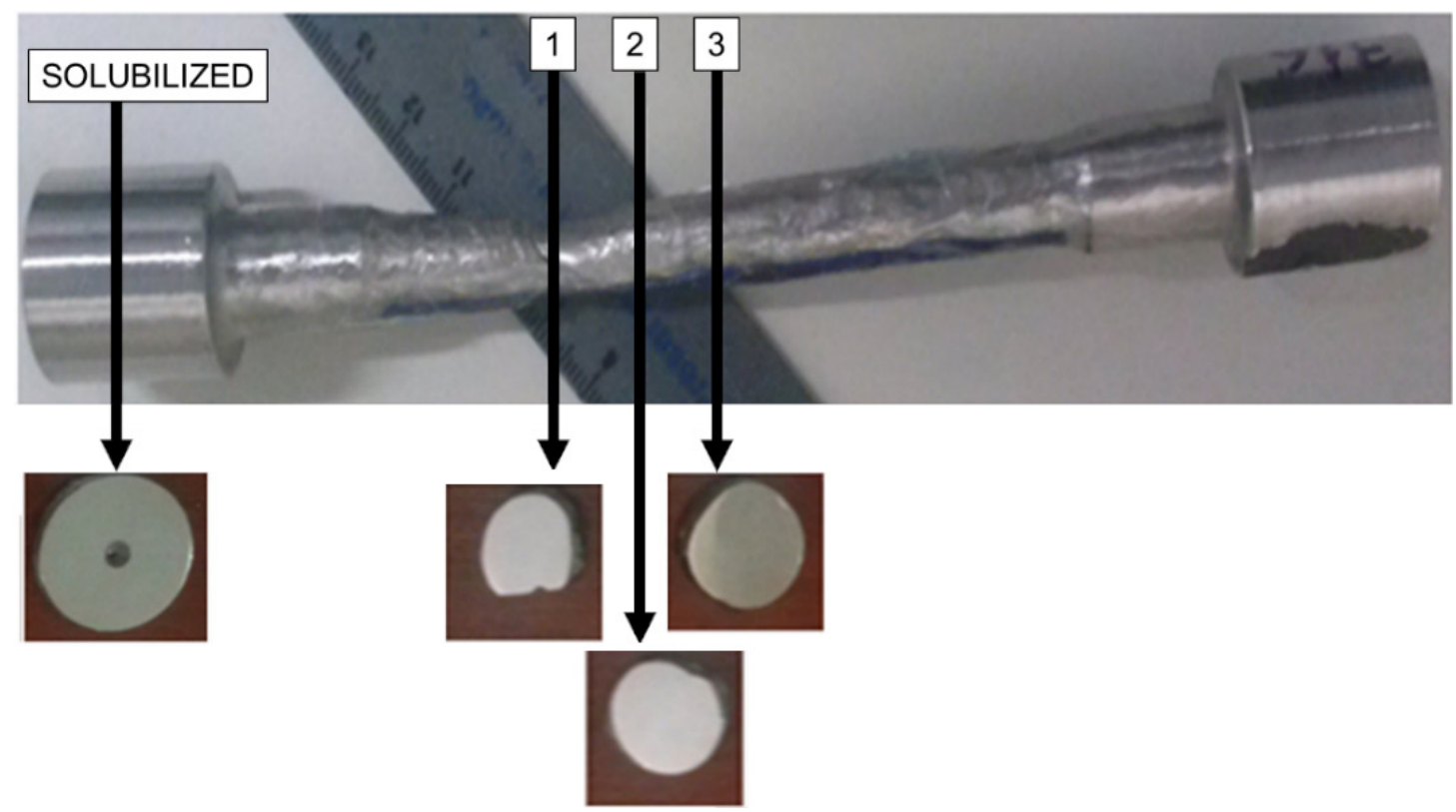

Figure 1. Cross sections of BS EN $10283 \mathrm{~N}^{\circ} 14587$ stainless steel subjected to cold deformations. 


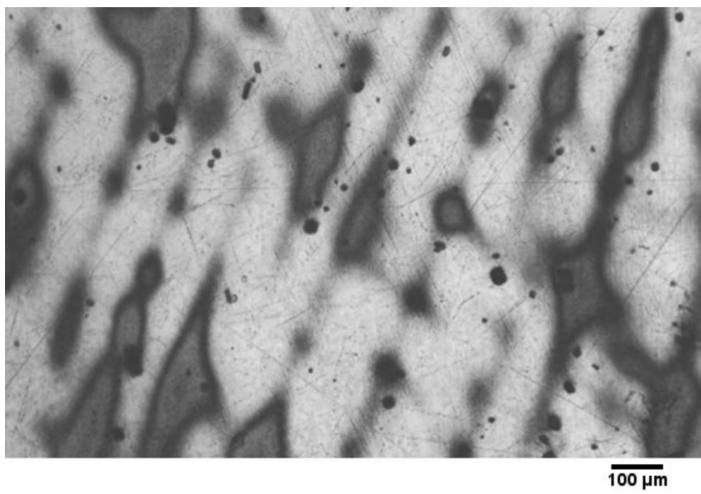

Figure 2. Dendritic microstructure of solubilized superaustenitic steel (Aqua Regia - MO).

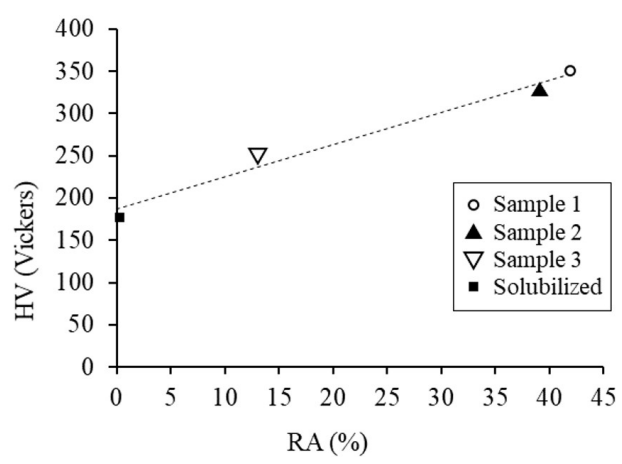

Figure 3. Values of the hardness (HV) and area reductions (RA) on superaustenitic stainless steel.

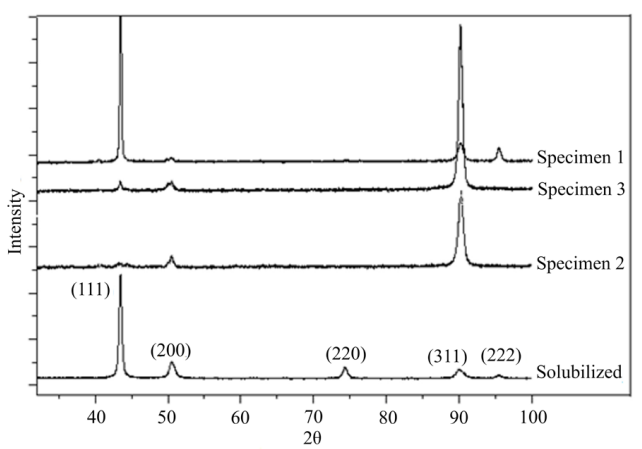

Figure 4. X-ray diffraction (XRD) patterns in BS EN 10283 $\mathrm{N}^{\circ} 14587$ steel: austenite peaks intensities of the solubilized and deformed regions.

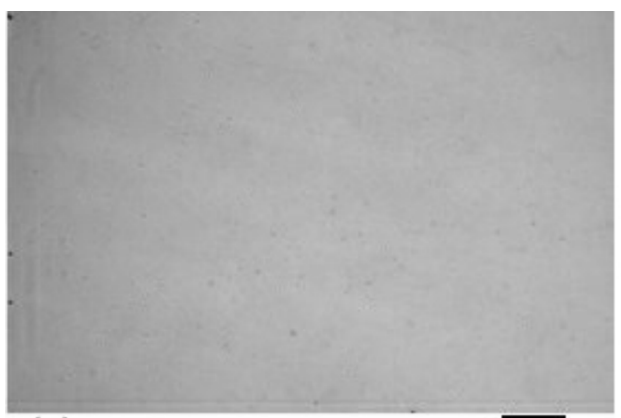

(a)

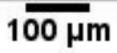

this element avoids the formation of strain-induced martensite and hardening occurs with the formation of sliding bands ${ }^{16}$.

Regarding the deformation imposed by the tensile test on steel, the results are shown in Table 2 and the measured areas of the specimens are shown in Table 3 . In the solubilized region there was no deformation and the small thickness ensures the faces similarity. The area reduction in Figure 3 due to cold deformation promotes a linear increase in steel hardness, however, the residual stresses are not enough to form the strain-induced martensite, as noted by the X-ray diffraction patterns in Figure 4. In deformed regions of the steel, the intensities of the peaks can be explained by the reorientation of the crystallographic planes after deformation ${ }^{17}$. The solubilized superaustenitic showed the pattern of austenite spectrum, with greater intensity in the plan (111), characteristic of the FCC structure. The reflections (111) $\gamma,(200) \gamma,(220) \gamma$, and (311) $\gamma$ corresponding to the austenite phase were identified and corroborate with several results in the literature ${ }^{18,19}$.

Regarding the corrosion tests, after immersion in sodium chloride, there is no formation of pits and oxides on the surface, according to previous results on superaustenitic stainless steels, as seen in Figure $5^{20}$. This does not mean that there was not deleterious phases, but the content was not enough to reduce the corrosion resistance in the electrolyte $^{21}$. In superaustenitic stainless steels, the stability of the passive film can be explained by different authors. Willenbruch et al. ${ }^{22}$ showed that an oxide layer of chromium and molybdenum can form on the surface and it blocks the action of chloride ions and the formation of the pits. Another explanation is the synergistic effect of nitrogen and molybdenum on the passive film, which inhibits anodic

Table 2. Yield strength (YS), tensile strength (TS) and elongation (E) of superaustenitic stainless steel.

\begin{tabular}{cccc}
\hline BS EN 10283 N N $^{\circ} 4587$ & YS (MPa) & TS (MPa) & E (\%) \\
\hline Standard & 220 & 480 & 30 \\
\hline Obtained & $262 \pm 10$ & $490 \pm 4$ & $40 \pm 2$ \\
\hline
\end{tabular}

Table 3. Values of the initial areas, final areas and area reduction (AR) of the deformed specimens.

\begin{tabular}{cccc}
\hline & Specimen 1 & Specimen 2 & Specimen 3 \\
\hline Initial areas & 120 & 120 & 120 \\
\hline Final areas & $70 \pm 2$ & $74 \pm 2$ & $107 \pm 4$ \\
\hline AR & $42 \%$ & $39 \%$ & $13 \%$ \\
\hline
\end{tabular}

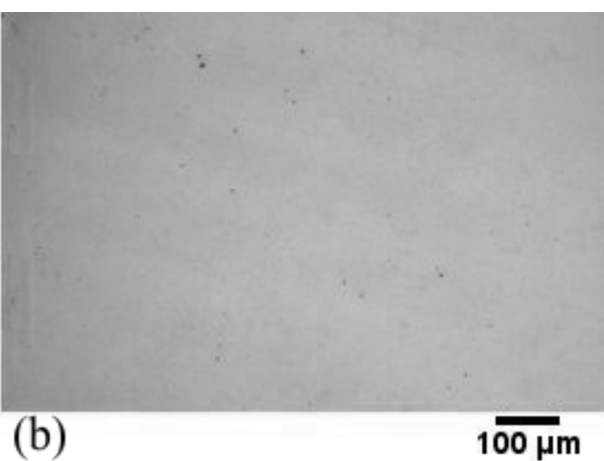

Figure 5. Regions on the surface of superaustenitic stainless steel before (a) and after (b) corrosion tests without attack. The black dots represent typical refractory oxides (MO). 
dissolution and improves pitting corrosion resistance of the material $^{22,23}$.

As can be seen in the linear polarization in Figure 6, near $0.92 \mathrm{mV}$, the oxygen evolution takes part of the process and the dominant reaction is the oxidation of water hydroxyl. This process generates an anodic current increase ${ }^{24-26}$. With this type of reaction, it is very difficult to distinguish the current due to the metal corrosion from the current of the

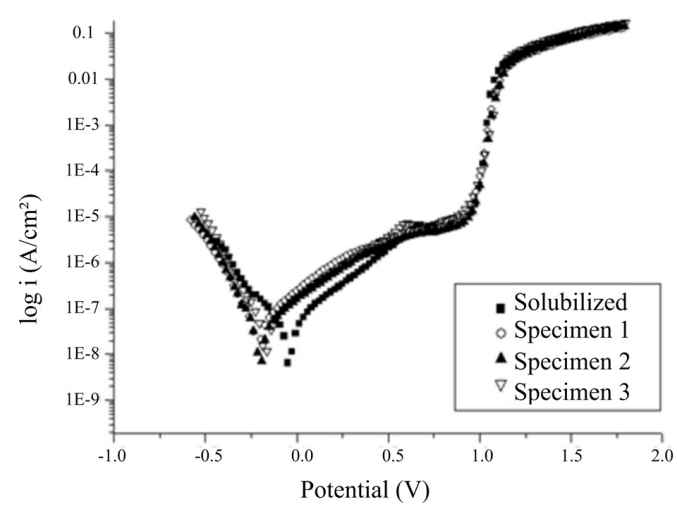

Figure 6. Values of corrosion potential obtained after linear polarization in $3.5 \% \mathrm{NaCl}$ solution. The solubilized specimen has a higher value, although not significant.

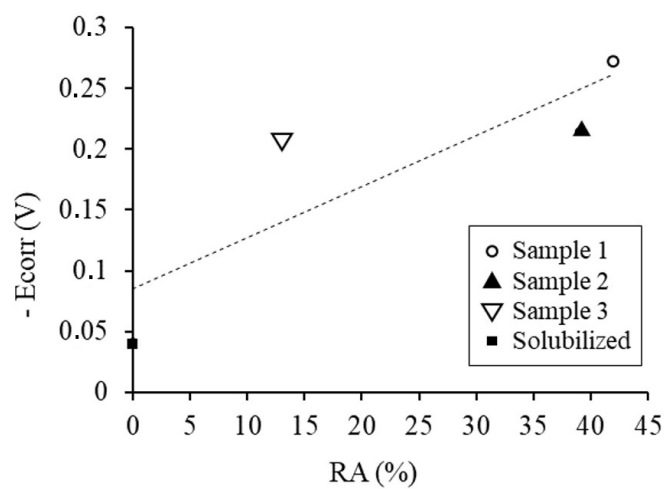

Figure 7. Effect of the area reduction on the corrosion potential of superaustenitic stainless steel in $3.5 \% \mathrm{NaCl}$ solution.

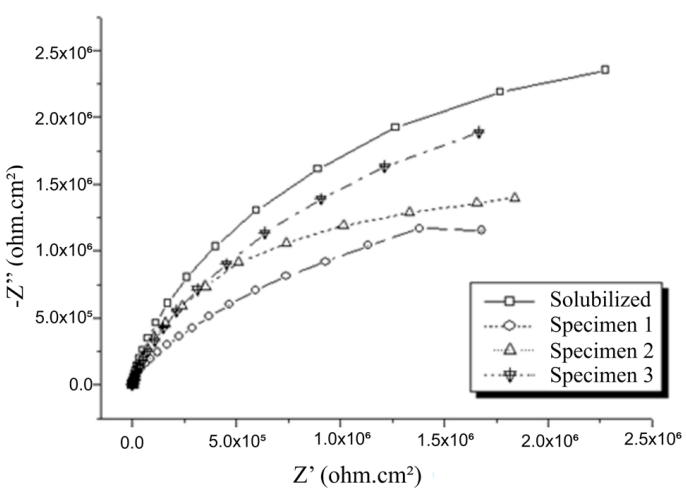

Figure 8. Nyquist Diagram and the effect of area reduction on the charge transfer resistance of the superaustenitic stainless steel $(3.5 \% \mathrm{NaCl}$ solution). water dissociation $^{27}$. The absence of pits on its surface is the main reason for the polarization curves do not present hysteresis ${ }^{20}$.

Regarding Figure 7, there is a decrement in the equilibrium potential $\left(\mathrm{E}_{\text {corr }}\right)$ with area reduction. The values are in accordance with the literature and indicate $-200 \mathrm{mV}$ for superaustenitic steel against $-328 \mathrm{mV}$ for $316 \mathrm{~L}$ in solution with $3.5 \%$ sodium chloride ${ }^{25,26}$. In addition, the Nyquist diagram in Figure 8 shows that the charge transfer resistance reduces with area reduction increasing. Even with the absence of strain-induced martensite and stress corrosion, the cold deformation was sufficient to reduce the charge transfer resistance ${ }^{26,28}$. In fact, it is possible that the hardening was caused by shear bands and dislocation locking ${ }^{16}$.

\section{Conclusions}

It is possible to conclude that:

- There is no pitting on surfaces of superaustenitic steel after corrosion tests in a 3.5\% sodium chloride solution;

- There is no strain-induced martensite with the deformation caused by the tensile tests at room temperature;

- The cold deformation promotes a linear increase in hardness with the area reduction.

\section{Acknowledgements}

The authors thank Grupo Metal Foundry for the superaustenitic stainless steel specimens and Ifes for financial support.

\section{References}

1. Speidel MO, Pedrazzoli RM. High nitrogen stainless steels in chloride solutions. Mater Perform. 1992;31(9):59-62.

2. Holmes B, Gladman T, Pickering FB. BSC Research Report PROD/PM/5762/12/72/A. Oxford: Oxford Brookes; 1972.

3. Padilha AF, Rios PR. Decomposition of austenite in stainless steel. ISIJ Int. 2002;42(4):325-37.

4. Mangonon PL, Thomas G. Structure and properties of thermal-mechanically treated 304 stainless steel. Metall Trans. 1970;1(6):1587-94.

5. ISSF: International Stainless Steel. Stainless steel and CO2: facts and scientific observations [Internet]. [cited $2020 \mathrm{Apr}$ 28]. Available from: https://www.worldstainless.org/files/issf/ non-image-files/PDF/ISSF Stainless Steel and CO2.pdf

6. Lilijas M. Development of superaustenitic stainless steel. In: IIW-95 Annual Assembly; 1995 June 12-13; Stockholm, Sweden. Proceedings. USA: International Institute of Welding; 1995.

7. Fredriksson H. Solidification and casting of metals. Shefield: Metals Society; 1979

8. Suutala N, Moisio T. Solidification technology in the foundry and casthouse. Conventry: Metals Society; 1980.

9. Gravalos MT, Martins M, Diniz AE, Mei PR. Efeito da usinagem na estrutura e propriedades mecânicas do aço superaustenitico ASTM A351 CN3MN. Rev Esc Minas (Online). 2007;60(1):83-8.

10. Ritoni M, Mei PR, Martins M. Efeito do tratamento térmico de solubilização na microestrutura e nas propriedades de impacto do aço inoxidável superaustenitico ASTM A 744 Gr.CN3MN. Rev Esc Minas (Online). 2010;63(1):13-20. 
11. Dafé S, Sicupira F, Matos F, Cruz N, Moreira D, Santos D. Effect of cooling rate on $\left(\varepsilon, \alpha^{\prime}\right)$ martensite formation in twinning/ transformation-induced plasticity Fe-17Mn-0.06C steel. Mater Res. 2013;16(6):1229-36.

12. Naraghi R, Hedström P, Borgenstam A. Spontaneous and deformation-induced martensite in austenitic stainless steels with different stability. Steel Res Int. 2011;82(4):337-45.

13. Curtze S, Kuokkala V-T. Effects of temperature and strain rate on the tensile properties of twip steels. Revista Matéria. 2010;15(2):157-63.

14. Jun JH, Choi CS. Variation of stacking fault energy with austenitic grain size and its effect on the Ms temperature of $\gamma$ $\rightarrow \varepsilon$ martensitic transformation in Fe-Mn alloy. Mater Sci Eng A. 1998;257(2):353-6.

15. Bowkett MW, Harries DR. Martensitic transformation in cold rolled EM 58B (Type 321) austenitic stainless steel. Harwell: AERE; 1978.

16. Kestenbach HJ. Efeito da energia de falha de empilhamento sobre a deformação plástica em aços inoxidáveis austeníticos. Metalurgia. 1976;32:181-6.

17. Pinto H. Effect of temperature and environment of the deformation mechanisms of austenitic steels during cryogenic wear [thesis]. Berlin: Technische Universität Berlin; 2005.

18. Ritoni M, Martins M, Nascimento FC, Mei PR. Phase transformations on ASTM a $744 \mathrm{Gr}$. CN3MN superaustenitic stainless steel after heat treatment. Defect and Diffusion Forum. 2011;312-315:56-63.

19. Borges FCN, Oliveira WR, Kublitski J. Mechanical, structural and tribological properties of superaustenitic stainless steel submitted at solution heat treatment. Revista Matéria. 2015;20(1):160-8.

20. Cardoso JL, Mandel M, Krüger L, Herculano LFG, Lima-Neto P, Silva MJG. Corrosion behavior of austenitic stainless steels in $\mathrm{CO}_{2}$-saturated synthetic oil field formation water. Mater Res. 2019;22(4):e20180334.

21. Cardoso JL, Cavalcante ALSN, Vieira RCA, Lima-Neto P, Silva MJG. Pitting corrosion resistance of austenitic and superaustenitic stainless steels in aqueous medium of $\mathrm{NaCl}$ and $\mathrm{H}_{2} \mathrm{SO}_{4}$. Mater Res. 2016;31(12):1755-63.

22. Willenbruch RD, Clayton CR, Oversluizen M, Kim D, Lu Y. An XPS and electrochemical study of the influence of molybdenum and nitrogen on the passivity of austenitic stainless steel. Corros Sci. 1990;31:179-90.

23. Nagarajan S, Karthega M, Rajendran N. Pitting corrosion studies of super austenitic stainless steels in natural sea water using dynamic electrochemical impedance spectroscopy. J Appl Electrochem. 2007;37:195-201.

24. Khatak HS, Raj B, editors. Corrosion of austenitic stainless steels: mechanism, mitigation and monitoring. Cambridge: Woodhead Publishing; 2002.

25. Mori G, Bauernfeind D. Pitting and crevice corrosion of superaustenitic stainless steels. Material and Corrosion. 2004;55(3):164-73.

26. Nagarajan S, Rajendran N. Crevice corrosion behavior of superaustenitic stainless steels: dynamic electrochemical impedance spectroscopy and atomic force microscopy studies. Corros Sci. 2009;51(2):217-24.

27. Bandy R, Cahoon JR. Effect of composition on the electrochemical behavior of austenitic stainless steel in Ringer's solution. Corrosion. 1977;33(6):204-8.

28. Jang $\mathrm{H}$, Kwon $\mathrm{H}$. In situ study on the effects of $\mathrm{Ni}$ and Mo on the passive film formed on $\mathrm{Fe}-20 \mathrm{Cr}$ alloys by photo electrochemical and Mott-Scotty techniques. J Electroanal Chem. 2006;590(2):120-5. 